\title{
Discovery Learning untuk Meningkatkan Kuantitas dan Kualitas Pertanyaan dan Pernyataan Siswa SMA pada Pembelajaran Biologi
}

\author{
Almira Rahma*, Sri Widoretno, Nurmiyati \\ Pendidikan Biologi FKIP Universitas Sebelas Maret Surakarta, \\ J1. Ir. Sutami 36 A, Surakarta, 57126, Kentingan, Surakarta, Indonesia \\ Surat elektronik: malmirahma@gmail.com
}

\begin{abstract}
ABSTRAK
Penelitian bertujuan meningkatkan kuantitas dan kualitas pertanyaan dan pernyataan siswa melalui penerapan discovery learning pada pembelajaran biologi SMA. Penggunaan discovery learning karena pembelajaran discovery merupakan salah satu model yang dapat memenuhi kebutuhan pembelajaran kurikulum 2013. Penelitian dilakukan selama 3 siklus, dengan subjek penelitian adalah 28 siswa kelas XI IPS 1 SMA Negeri 5 Surakarta. Data diperoleh dari observasi, wawancara, dan dokumentasi sebagai metode penelitian kualitatif. Validasi data menggunakan teknik triangulasi. Teknik analisis data menggunakan analisis kualitatif. Analisa pertanyaan dan pernyataan menggunakan rubrik Taksonomi Bloom terevisi. Hasil penelitian menunjukkan terjadi peningkatan kuantitas dan kualitas pertanyaan dan pernyataan siswa pada pembelajaran biologi dengan penerapan discovery learning. Peningkatan kuantitas merupakan pertambahan jumlah pertanyaan dan pernyataan dari baseline sebanyak 65 pertanyaan dan 157 pernyataan. Masing-masing siklus ditunjukkan dengan pertambahan pertanyaan dan pernyataan dari baseline yang diperoleh dari hasil observasi sebanyak 29 pertanyaan dan 56 pernyataan menjadi 84 pertanyaan dan 213 pernyataan di siklus 1, 88 pertanyaan dan 157 pernyataan di siklus 2, serta 94 pertanyaan dan 208 pernyataan di siklus 3. Peningkatan kualitas merupakan pertambahan tingkat kognitif yang ditunjukkan dengan pergeseran proses berpikir dari C2 menjadi C5, serta pergeseran dimensi faktual menjadi dimensi pengetahuan di siklus 1, siklus 2, dan siklus 3 . Kesimpulan dari penelitian adalah penerapan model discovery learning mampu meningkatkan kuantitas dan kualitas pertanyaan dan pernyataan siswa SMA pada pembelajaran biologi.

Kata kunci: discovery learning, pembelajaran biologi
\end{abstract}

\begin{abstract}
Title: Discovery Learning Improving the Quality and Quantity of Question and Statements Senior High School Students' on Biology Learning. The research aim to improve the quantity and quality of the students' questions and statements through the implementation of discovery learning in high school biology teaching. The research was conduct in 3 cycles. the research subjects were 28 students of class XI IPS 1 SMA Negeri 5 Surakarta. The data was obtained from learning observation, interview, and documentation.Data validation used triangulation technique. Data analysis used qualitative analysis. Question and statement analysis used revised Bloom Taxonomy rubric. The results showed an increase in the quantity and quality of questions and statements of students on biology learning with the implementation of discovery learning. The enhancement in quantity is an increase in the number of questions and statements from the baseline of 65 questions and 157 statements. Each cycle is shown by the addition of questions and statements from the baseline obtained from the observation of 29 questions and 56 statements to 84 questions and 213 statements in cycle 1, 88 questions and 157 statements in cycle 2, and 94 questions and 208 statements in cycle 3. Quality enhancement was the increase of cognitive level shown by the shift of thought process from C2 to C5, and the shift of factual dimension to the knowledge dimension in cycle 1, cycle 2, and cycle 3 . The research conclude that implementation of discovery learning model can enhance the quantity and quality questions and statements of high school students on biology learning.
\end{abstract}

Keyword: discovery learning, biology learning

Copyright (C) 2017 Universitas Ahmad Dahlan

\section{Pendahuluan}

Proses pembelajaran di kelas merupakan interaksi timbal balik antara guru dengan siswa dalam situasi edukatif untuk mencapai tujuan belajar (Rustaman,
2007). Proses pembelajaran menurut Permendiknas Nomor 65 tahun 2013 adalah pembelajaran yang interaktif, inspiratif, menyenangkan, menantang, dan memotivasi siswa untuk berpartisipasi aktif. Partisipasi aktif siswa dalam proses pembelajaran terlihat dari 
berpikir dan berkomunikasi aktif melalui bertanya dan menyatakan pendapat sebagai respon dari pertanyaan dan pernyataan siswa maupun guru (Mayer, 2009; Cho, et al., 2012), sehingga bertanya dan menyatakan pendapat adalah indikator pembelajaran interaktif (Jean, Carron, \& Pernelle, 2012), yang teridentifikasi melalui pertanyaan dan pernyataan. Pertanyaan dan pernyataan menurut Clough (2007) dan Mercier (2011) merupakan komponen utama dalam proses pembelajaran yang mencerminkan proses berpikir siswa.

Pertanyaan dan pernyataan siswa kelas XI IPS 1 diperoleh 29 pertanyaan dan 66 pernyataan dari 28 siswa. Pertanyaan terdiri dari 6,89\% C1 faktual, 37,56\% C1 konseptual, 48,27\% C2 konseptual, 3,44\% C3 konseptual, dan 3,44\% C4 konseptual. Pernyataan terdiri dari 80,3\% C1 faktual, 10,6\% C1 konseptual, dan 9,09\% C2 konseptual. Pertanyaan dan pernyataan siswa didominasi oleh proses kognitif C1 dan C2 pada dimensi fakta dan konsep yang merupakan kategori berpikir rendah (Marin \& Halpern, 2011; Sim, 2013), sementara berpikir tingkat tinggi merupakan salah satu kemampuan yang dibutuhkan di abad 21 (Saavedra \& Opfer, 2012).

Berpikir tingkat tinggi meliputi berpikir analisis, evaluasi, menyimpulkan, keterampilan berpikir kritis, dan kreatif yang ditunjukan melalui pertanyaan dan pernyataan (Almeida, 2011; Barak \& Dori, 2009). Pertanyaan dan pernyataan yang memfasilitasi interaksi dalam proses pembelajaran diharapkan mampu meningkatkan kemampuan berpikir tingkat tinggi siswa.

Berpikir tingkat tinggi berfungsi untuk memecahkan masalah dan mengambil keputusan (making decision) melalui informasi dasar, identifikasi variabel dan menghubungkan pengetahuan awal ke masalah yang ditemukan untuk dipelajari (Barnett \& Francis, 2012). Berpikir tingkat tinggi difasilitasi melalui pertanyaan dan pernyataan yang ditemui dalam tahapan perumusan masalah dan tujuan pembelajaran (Blackwell, 2015).

Berpikir tingkat tinggi diperlukan untuk penyusunan jawaban sementara yang berasal dari hasil pengamatan berbagai fenomena atau informasi untuk dinyatakan melalui pernyataan (Thomas, Dougherty, \& Buttaccio, 2014). Hasil pengamatan berbagai fenomena atau informasi sebagai awal pembuktian jawaban sementara. Pembuktian jawaban sementara memerlukan berpikir tingkat tinggi untuk menganalisis, menyintesis, menyatakan ide yang dimiliki, dan mengembangkan pengetahuan yang diperoleh (Rodzalana \& Saat, 2015), dengan mencari informasi dan ide melalui pertanyaan dan pernyataan (Chin \& Osborne, 2010).

Hasil analisis informasi dan ide selanjutnya dituangkan dalam rumusan kesimpulan. Perumusan kesimpulan dengan menghubungkan beberapa variabel memerlukan proses penalaran melalui berpikir tingkat tinggi yang melibatkan jenis proses berpikir untuk memecahkan masalah dan membuat keputusan melalui pengajuan pernyataan (Dwyer, Hogan, \& Stewart,
2011). Pengajuan pernyataan yang melibatkan proses berpikir mendukung kegiatan untuk mengkonfirmasi rumusan kesimpulan yang telah dirumuskan dengan jawaban sementara (Mercier \& Sperber, 2011).

Pertanyaan dan pernyataan yang melibatkan berpikir tingkat tinggi melalui kegiatan perumusan masalah, penyusunan dan pembuktian jawaban sementara, perumusan kesimpulan, dan mengkomunikasikan rumusan kesimpulan merupakan tahapan pembelajaran discovery (Kwan \& Wong, 2015). Discovery learning adalah salah satu model yang dapat memenuhi kebutuhan pembelajaran kurikulum 2013, dengan demikian discovery learning dapat diterapkan pada pembelajaran biologi saat ini. Discovery learning merupakan pembelajaran konstruktivis yang memberikan kesempatan kepada siswa untuk aktif membangun pengetahuan sendiri (Kwan \& Wong, 2015; Alfieri, et al., 2011) dengan melibatkan pertanyaan, pernyataan, pengujian hipotesis, perencanaan, pelaksanaan dan evaluasi ilmiah eksperimen (Kunsting, Kempf, \& Wirth, 2013). Fase dalam discovery learning menurut Vermaans (2002) terdiri dari 5 tahapan yang meliputi orientation, hypothesis generation, hypothesis testing, conclusion, regulation. Tahapan orientasi hingga regulasi pada discovery learning didukung oleh tingkatan berpikir metakognitif yang merupakan berpikir tingkat tinggi (Kunsting, Kempf, \& Wirth, 2013).

Penerapan discovery learning pada pembelajaran biologi bertujuan untuk meningkatkan kuantitas dan kualitas pertanyaan dan pernyataan siswa sebagai indikator berpikir.

\section{Metode Penelitian}

Penelititan dilakukan selama 3 siklus pada materi sistem reproduksi yang diperoleh melalui empat tahapan yaitu perencanaan, pelaksanaan, observasi, dan refleksi. Penelitian berakhir di siklus 3 karena berbagai pertimbangan yaitu: 1) teridentifikasi peningkatan kuantitas dan kualitas pertanyaan dan pernyataan, 2) waktu yang terbatas, 3) materi yang sesuai silabus pembelajaran. Subjek penelitian adalah siswa kelas XI IPS 1 SMA N 5 Surakarta. Pengambilan data dilakukan dengan teknik observasi pada proses pembelajaran untuk mengidentifikasi peningkatan kuantitas dan kualitas pertanyaan dan pernyataan melalui discovery learning, wawancara untuk mengonfirmasi pertanyaan dan pernyataan yang diajukan siswa, serta dokumentasi sebagai data pendukung. Validasi data menggunakan triangulasi. Teknik analisis menggunakan analisis kualitatif. Analisa pertanyaan dan pernyataan menggunakan instrument sesuai rubrik Taksonomi Bloom terevisi.

\section{Hasil dan Pembahasan}

Berdasarkan penelitian diperoleh hasil kuantitas dan kualitas pertanyaan dan pernyataan yang menunjukkan 
peningkatan secara fluktutatif. Hasil penelitian disajikan pada Tabel 1 dan Tabel 2.

Tabel 1. Persebaran Kuantitas dan Kualitas Pertanyaan di Seluruh Siklus.

\begin{tabular}{|c|c|c|c|c|c|}
\hline \multirow{2}{*}{$\begin{array}{c}\text { Dimensi } \\
\text { Pengetahuan }\end{array}$} & \multirow{2}{*}{$\begin{array}{l}\text { Proses } \\
\text { berpikir }\end{array}$} & \multicolumn{4}{|c|}{ Siklus ke- } \\
\hline & & Pra & S1 & $\mathrm{S} 2$ & S3 \\
\hline \multirow[t]{6}{*}{ Faktual } & $\mathrm{C} 1$ & 2 & 1 & 2 & - \\
\hline & $\mathrm{C} 2$ & - & - & - & - \\
\hline & C3 & - & - & - & - \\
\hline & $\mathrm{C} 4$ & - & - & - & - \\
\hline & C5 & - & - & 1 & 1 \\
\hline & C6 & - & - & - & - \\
\hline \multirow[t]{6}{*}{ Konseptual } & C1 & 8 & 19 & 21 & 8 \\
\hline & $\mathrm{C} 2$ & 17 & 49 & 52 & 61 \\
\hline & C3 & 1 & 1 & - & 1 \\
\hline & $\mathrm{C} 4$ & 1 & 4 & 9 & 15 \\
\hline & C5 & - & - & - & 3 \\
\hline & C6 & - & - & - & \\
\hline \multirow[t]{6}{*}{ Prosedural } & C1 & - & 9 & 2 & 2 \\
\hline & $\mathrm{C} 2$ & - & 2 & 1 & 3 \\
\hline & C3 & - & - & - & - \\
\hline & $\mathrm{C} 4$ & - & - & - & - \\
\hline & C5 & - & - & - & - \\
\hline & C6 & - & - & - & - \\
\hline \multirow[t]{6}{*}{ Metakognisi } & C1 & - & - & - & - \\
\hline & $\mathrm{C} 2$ & - & - & - & - \\
\hline & C3 & - & - & - & - \\
\hline & $\mathrm{C} 4$ & - & - & - & - \\
\hline & C5 & - & - & - & - \\
\hline & C6 & - & - & - & - \\
\hline Jumlah & & 29 & 85 & 88 & 94 \\
\hline
\end{tabular}

Tabel 1 menunjukkan hasil pertanyaan siswa yang meningkat dari pra-siklus sampai dengan siklus 3. Hasil perolehan pertanyaan siswa di siklus 1 teridentifikasi 85 pertanyaan dengan persebaran kualitas pertanyaan pada dimensi berpikir C1 sampai dengan C4, dan pada dimensi pengetahuan faktual, konseptual, serta prosedural. Kuantitas pertanyaan di siklus 1 telah menagalami peningkatan dari prasiklus sebanyak 56 pertanyaan yang tersebar hingga dimensi prosedural. Persebaran pertanyaan di tingkat berpikir C1 faktual yang mengalami penurunan jumlah, serta $\mathrm{C} 1$ dan $\mathrm{C} 2$ prosedural menunjukkan terjadinya peningkatan kualitas pertanyaan sebagai peningkatan proses berpikir.

Pertanyaan di siklus 2 teridentifikasi 88 pertanyaan dengan persebaran kualitas pertanyaan di dimensi berpikir C1 sampai dengan C5, pada dimensi pengetahuan faktual, konseptual, serta prosedural. Pertanyaan di siklus 2 telah mengalami peningkatan kuantitas dari siklus 1 sebanyak 3 pertanyaan. Peningkatan kualitas pertanyaan ditunjukkan dengan teridentifikasi pertanyaan C5 faktual serta C1 dan C2 prosedural sebagai peningkatan proses berpikir tingkat tinggi.

Hasil pertanyaan siswa siklus 3 teridentifikasi 94 pertanyaan yang tersebar di tingkat berpikir C1 sampai dengan C5 pada dimensi faktual, konseptual, dan prosedural. Peningkatan kuantitas pertanyaan di siklus 3 dari siklus 2 sebanyak 6 pertanyaan, sementara peningkatan kualitas pertanyaan terlihat pada kemampuan siswa mengajukan pertanyaan di proses berpikir C1, C2, C3, C4, dan C5.

Kualitas pertanyaan siswa berdasarkan Tabel 1 mengalami peningkatan yang ditunjukkan dengan pergeseran proses berpikir dan dimensi pengetahuan dari baseline di pra-siklus. Peningkatan kualitas pertanyaan di siklus 1 sampai dengan siklus 3 berbeda-beda yang secara keseluruhan menunjukkan pertanyaan di pra-siklus mengalami pergeseran proses berpikir di siklus 2 dan siklus 3 , serta pergeseran dimensi pengetahuan di siklus 1 sampai dengan siklus 3 pada dimensi prosedural.

Pertanyaan prosedural mengalami pergeseran pada proses berpikir C1 dan C2 di siklus 1, siklus 2, dan siklus 3 , sehingga pertanyaan di siklus 1 sampai dengan siklus 3 teridentifikasi pada dimensi faktual, konseptual, dan prosedural. Kualitas pertanyaan terhadap proses berpikir mengalami peningkatan ditunjukkan dengan proses berpikir teridentifikasi pada C1, C2, C3, dan C4 di siklus 1, serta siklus 2 dan siklus 3 mulai teridentifikasi adanya proses berepikir C1 sampai dengan C5 pada pertanyaan faktual dan konseptual.

Pertanyaan faktual mengalami peningkatan dari C1 menjadi C5 di siklus 2 dan siklus 3. Pertanyaan konseptual di siklus 2 teridentifikasi pada proses berpikir C1, C2, C4, dan C5, serta di siklus 3 mengalami peningkatan proses berpikir dari C1, C2, C3, C4 menjadi C5 yang sebelumnya di siklus 1 dan siklus 2 belum teridentifikasi. Pertanyaan prosedural teridentifikasi pada proses berpikir C1 dan C2 dari siklus 1 sampai dengan siklus 3 .

Tabel 2 menunjukkan hasil pernyataan siswa mengalami fluktuatif dari siklus 1 sampai dengan siklus 3. Hasil perolehan pernyataan siswa di siklus 1213 pernyataan dengan persebaran kualitas pernyataan pada dimensi berpikir C1 sampai dengan C5, dan pada dimensi pengetahuan faktual, konseptual, serta prosedural. Kuantitas pernyataan di siklus 1 telah mengalami peningkatan dari prasiklus sebanyak 157 pernyataan yang tersebar sampai dengan dimensi prosedural. Persebaran pernyataan yang teridentifikasi di dimensi berpikir C3 dan C5 faktual, C3 konseptual serta C1 prosedural menunjukkan terjadinya peningkatan kualitas pernyataan sebagai peningkatan proses berpikir di siklus 1 .

Siklus 2 mengalami penurunan kuantitas pernyataan dari siklus 1 sebanyak 56 pernyataan (26,29\%). Namun, tetap mengalami peningkatan dibandingkan prasiklus. Pernyataan di siklus 2 teridentifikasi 157 pernyataan yang tersebar pada dimensi berpikir C1 sampai dengan C4, serta pada dimensi pengetahuan faktual, konseptual, serta prosedural. Kualitas pernyataan di siklus 2 tidak menunjukkan peningkatan yang signifikan ditunjukkan dengan hanya teridentifikasi pertanyaan C4 konseptual sebagai indikator berpekir tingkat tinggi, sedangkan pernyataan di proses berpikir C1, C2, dan C3 
merupakan indikator berpikir tingkat rendah. Penurunan kualitas pernyataan di siklus 2 disebabkan beberapa faktor diantaranya 1) topik materi pembelajaran yang lebih sedikit, 2) pemotongan jam pelajaran, 3) keterlibatan siswa yang tidak maksimal.

Siklus 3 mengalami peningkatan kualitas pernyataan kembali sebanyak 51 pernyataan $(32,48 \%)$ dari siklus 2. Pernyataan di siklus 3 menunjukkan peningkatan kualitas tertinggi yang ditunjukkan dengan teridentifikasi pernyataan yang tersebar pada dimensi berpikir C1 sampai dengan C5 faktual maupun konseptual, serta peningkatan di C2 prosedural.

Tabel 2. Persebaran Kuantitas dan Kualitas Pernyataan di Seluruh Siklus.

\begin{tabular}{cccccc}
\hline \multirow{2}{*}{$\begin{array}{c}\text { Dimensi } \\
\text { Pengetahuan }\end{array}$} & Proses & \multicolumn{4}{c}{ Siklus ke- } \\
\cline { 3 - 6 } & berpikir & Pra & S1 & S2 & S3 \\
\hline \multirow{5}{*}{ Faktual } & C1 & 9 & 21 & 18 & 3 \\
& C2 & - & - & 13 & 9 \\
& C3 & - & 1 & 1 & 2 \\
& C4 & - & - & - & - \\
& C5 & - & 1 & - & 2 \\
& C6 & - & - & - & - \\
Konseptual & C1 & 36 & 100 & 70 & 96 \\
& C2 & 11 & 69 & 45 & 66 \\
& C3 & - & 2 & - & 1 \\
& C4 & - & - & 1 & 7 \\
& C5 & - & - & - & 2 \\
& C6 & - & - & - & - \\
& C1 & - & 19 & 9 & 17 \\
& C2 & - & - & - & 3 \\
& C3 & - & - & - & - \\
Prosedural & C4 & - & - & - & - \\
& C5 & - & - & - & - \\
& C6 & - & - & - & - \\
& C1 & - & - & - & - \\
& C2 & - & - & - & - \\
& C3 & - & - & - & - \\
& C4 & - & - & - & - \\
& C5 & - & - & - & - \\
& C6 & & & & - \\
& & 56 & 213 & 157 & 208 \\
\hline \multirow{5}{*}{ Metakognisi } & & & & &
\end{tabular}

Pernyataan siswa secara keseluruhan berdasarkan Tabel 2 menunjukkan kualitas mengalami peningkatan yang ditunjukkan dengan pergeseran proses berpikir dan dimensi pengetahuan dari baseline di pra-siklus. Pernyataan siswa di pra-siklus teridentifikasi pada dimensi pengetahuan faktual dan konseptual di proses berpikir C1 dan C2 mengalami peningkatan yang berbeda-beda selama siklus 1 sampai dengan siklus 3 . Peningkatan ditunjukkan dengan teridentifikasi dimensi prosedural di siklus 1, siklus 2, dan siklus 3, serta peningkatan pada proses berpikir dari pernyataan C1 dan C2 di pra-siklus meningkat hingga proses berpikir C3, C4, dan C5 di siklus 1 sampai dengan 3.

Peningkatan kualitas proses berpikir pada dimensi faktual yaitu dari semula C1 menjadi C3 dan C5 di siklus 1, C2, C3, dan C5 di siklus 2 dan siklus 3. Peningkatan proses berpikir juga terjadi pada dimensi konseptual dari C1 dan C2 menjadi C3 di siklus 1, C4 di siklus 2, serta C3, C4, dan C5 di siklus 3, sementara pernyataan prosedural hanya teridentifikasi pada proses berpikir C1 dari pada siklus 1 sampai dengan siklus 3 .

Pertanyaan dan pernyataan metakognisi dan proses berpikir C6 tidak teridentifikasi dari siklus 1 sampai dengan siklus 3. Hasil penelitian didukung oleh Pramesti (2015) dan Azis (2015), menyatakan bahwa pertanyaan paling jarang diajukan siswa selama proses pembelajaran menggunakan discovery learning adalah pertanyaan metakognisi. Pertanyaan dan pernyataan metakognisi yang tidak teridentifikasi menunjukkan bahwa siswa belum mampu untuk mengajukan pertanyaan ataupun pernyataan yang berhubungan dengan self-awarness (Pintrich, 2002).

Pertanyaan dan pernyataan pada proses berpikir C6 tidak teridentifikasi dikarenakan karena discovery learning merupakan pembelajaran yang menekankan sebatas pada penemuan dan pemahaman konsep (Alfieri, Aldrich, Brooks, \& Tenenbaum, 2011). Penemuan konsep dilakukan dengan pemberian masalah kepada siswa untuk menemukan jawaban atau informasi sendiri (Sarabeth, 2013), sementara pertanyaan dan pernyataan C6 merupakan pertanyaan dan pernyataan yang menandakan siswa telah mampu menciptakan suatu konsep baru yang diperoleh dari menggabungkan konsep lama dengan konsep baru yang dimilikinya (Anderson \& Krathwohl, et al., 2001).

Pertanyaan dan pernyataan yang diperoleh melalui pembelajaran discovery learning paling banyak ditemui pada dimensi konseptual, dimensi prosedural, dan paling sedikit dimensi faktual, sedangkan dimensi metakognisi belum teridentifikasi adanya pertanyaan dan pernyataan. Pertanyaan dan pernyataan yang diperoleh pada masingmasing tahapan discovery learning disajikan pada Gambar 1.

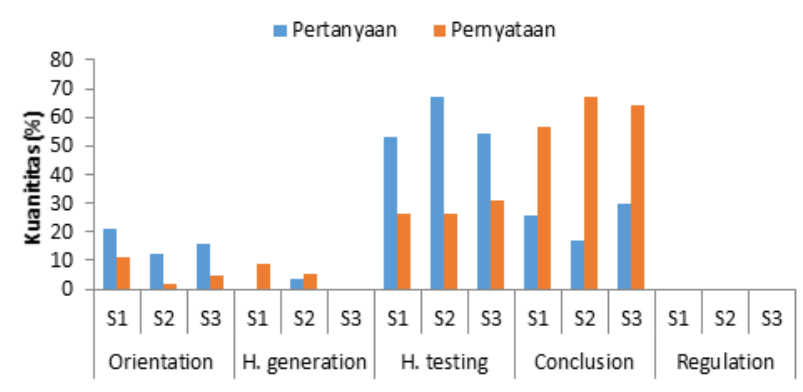

Tahap DiscoveryLearning

Gambar I. Kuantitas pertanyaan dan pernyataan pada tiap tahapan discovery learning

Gambar 1 menunjukkan setiap tahap discovery learning mengakomodasi pertanyaan dan pernyataan siswa untuk masing-masing dimensi pengetahuan di seluruh proses berpikir.

Kuantitas dan kualitas pertanyaan faktual, konseptual, dan prosedural lebih banyak ditemui pada tahapan hypothesis testing dibandingkan dengan tahapan lain, sedangkan pernyataan faktual, konseptual, dan prosedural lebih banyak ditemui pada tahapan 
conclusion. Pertanyaan faktual, konseptual, dan prosedural lebih banyak muncul pada tahapan hypothesis testing, karena dalam hypothesis testing siswa melakukan pengujian hipotesis dengan menyusun eksperimen, memprediksi, dan mengoleksi data melalui pengajuan pertanyaan (Saab, et al., 2005). Pernyataan faktual, konseptual, dan prosedural lebih banyak muncul pada tahapan conclusion, karena siswa mengkomunikasian hasil diskusi dan penarikan kesimpulan berdasarkan analisis data hasil kegiatan yang difasilitasi dengan pengajuan pernyataan (Veerman, 2002; Rahmawati, et al., 2015).

Tahapan discovery learning yang banyak mengakomodasi siswa untuk mengajukan pertanyaan adalah hypothesis testing, sedangkan tahapan yang kurang mengakomodasi pertanyaan adalah hypothesis generation. Tahapan discovery learning yang banyak mengakomodasi siswa untuk mengajukan pernyataan adalah tahapan conclusion, sedangkan tahapan yang kurang mengakomodasi pernyataan adalah orientation.

Tahapan orientation dari seluruh siklus mengakomodasi pertanyaan lebih banyak dibandingkan pernyataan, karena tahap orientation meliputi kegiatan klarifikasi, organisasi, dan investigasi berupa perumusan masalah yang perlu difasilitasi melalui pengajuan pertanyaan (Chin, 2004). Tahap hypothesis generation mengakomodasi pernyataan lebih banyak dibandingkan pertanyaan disebabkan kegiatan siswa pada tahap hypothesis generation meliputi kegiatan penyusunan jawaban sementara yang perlu difasilitasi melalui pengajuan pernyataan (Thomas, et al., 2014). Hasil penelitian menunjukkan dalam dua siklus yaitu siklus 1 dan siklus 3 tahap hypothesis generation tidak mengakomodasi pertanyaan.

Tahap hypothesis testing merupakan tahapan yang mengakomodasi pertanyaan paling banyak. Pertanyaan yang teridentifikasi lebih banyak dibandingkan pernyataan karena dilaksanakan dalam bentuk diskusi kelompok, sehingga menimbulkan interaksi antar siswa untuk menyelesaikan rumusan permasalahan yang didukung oleh pertanyaan (Rahmawati, et al., 2015). Pertanyaan merupakan faktor penting dalam pelaksanaan hypothesis testing. Hypothesis testing meliputi kegiatan pembuktian jawaban sementara yang memerlukan berpikir tingkat tinggi untuk menganalisis, menyintesis, menyatakan ide yang dimiliki, dan mengembangkan pengetahuan yang diperoleh dengan mencari informasi dan ide melalui pertanyaan (Rodzalana \& Saat, 2015; Chin \& Osborne, 2010).

Tahap conclusion mengakomodasi pernyataan paling banyak. Pernyataan yang teridentifikasi lebih banyak dibandingkan pertanyaan disebabkan tahap conclucion meliputi kegiatan pengkomunikasian hasil diskusi dan penarikan kesimpulan berdasarkan analisis data hasil kegiatan yang difasilitasi dengan pengajuan pernyataan, sehingga siswa lebih banyak mengajukan pernyataam daripada pertanyaan (Saab, et al., 2007).
Tahapan regulation tidak teridentifikasi adanya pertanyaan maupun pernyataan karena tahap regulation dari siklus 1 hingga siklus 3 tidak terlaksana. Tahap regulation tidak terlaksana disebabkan beberapa faktor antara lain keterbatasan waktu di setiap proses pembelajaran sehingga tidak muncul adanya pertanyaan dan pernyataan.

Pertanyaan dan pernyataan metakognisi dan proses berpikir C6 tidak teridentifikasi dari siklus 1 sampai dengan siklus 3. Hasil penelitian didukung oleh penelitian yang dilakukan Pramesti (2015) dan Azis (2015), menyatakan bahwa pertanyaan paling jarang diajukan siswa selama proses pembelajaran menggunakan discovery learning adalah pertanyaan metakognisi. Pertanyaan dan pernyataan metakognisi yang tidak teridentifikasi menunjukkan bahwa siswa belum mampu untuk mengajukan pertanyaan ataupun pernyataan yang berhubungan dengan self-awarness (Pintrich, 2002).

Pertanyaan dan pernyataan pada proses berpikir C6 tidak teridentifikasi dikarenakan karena discovery leanirng merupakan pembelajaran yang menekankan sebatas pada penemuan dan pemahaman konsep (Alfieri, Aldrich, Brooks, \& Tenenbaum, 2011). Penemuan konsep dilakukan dengan pemberian masalah kepada siswa untuk menemukan jawaban atau informasi sendiri (Sarabeth, 2013), sementara pertanyaan dan pernyataan C6 merupakan pertanyaan dan pernyataan yang menandakan siswa telah mampu menciptakan suatu konsep baru yang diperoleh dari menggabungkan konsep lama dengan konsep baru yang dimilikinya (Anderson \& Krathwohl, et al., 2001).

\section{Simpulan}

Berdasarkan hasil penelitian menunjukkan bahwa discovery learning mampu meningkatkan kuantitas dan kualitas pertanyaan dan pernyataan siswa SMA pada pembelajaran biologi. Peningkatan kuantitas ditunjukkan dengan pertambahan jumlah baseline pertanyaan dan pernyataan di siklus 1 sampai dengan siklus 3 . Peningkatan kualitas pertanyaan dan pernyataan ditunjukkan dengan pergeseran proses berpikir yang meningkat dari $\mathrm{C} 2$ menjadi $\mathrm{C} 5$, serta dari dimensi pengetahuan faktual menjadi prosedural di siklus 1, siklus 2, dan siklus 3 .

\section{Daftar Pustaka}

Alfieri, L., Aldrich, N. J., Brooks, P. J., \& Tenenbaum, H. R. (2011). Does discoverybased learning enhance instruction? Journal of Educational Psychology , 103 (1), $1-18$.

Almeida, P. A. (2011). Critical Thinking, Questioning and Creativity as Components of Intelligence. Social and Behavioral Sciences. 30, 357 - 362. Aveiro, Portugal: Elsevier Ltd

Anderson, L. W., Krathwohl, D. R., Airasian, P. W., Cruikshank, K. A., Mayer, R. E., Pintrich, P. R., et al. (2001). Kerangka Landasan untuk Pembelajaran, Pengajaran, dan Asesmen. Yogyakarta: Pustaka Pelajar. 
Barnett, J. E., \& Francis, A. L. (2012). Using Higher Order Thinking Questions to Foster Critical Thinking: A Classroom Study. Journal of Experimental Educational Psychology , 32 (2), 201-211.

Blackwell, W. (2015). Discovery Based Learning in the Life Science Kathleen M. Susman. New Jersey: Hoboken.

Chin, C. (2004). Students' questions: Fostering a Culture of Inquisitiveness in Science Classroom. School Science Review , 86 (314), 107-112.

Chin, C., \& Osborne, J. (2010). Students' Questions and Discursive Interaction: Their Impact on Argumentation During Collaborative Group Discussions in Science. Journal of Research in Science Teaching , 47(7), 883 908.

Cho, Y. H., Lee, S. Y., Jeong, D. W., Im, S. J., Choi, E. J., Lee, S. H., et al. (2012). Analysis of Questioning Technique During Classes in Medical Education. BMC Medical Education , 1-7.

Clough, M. P. (2007). What is So Important About Asking Questions? Iowa Science Teachers Journal , 34 (1).

Marin, L. M., \& Halpern, D. F. (2011). Pedagogy for Developing Critical Thinking in Adolescents: Explicit Instruction Produces Greatest Gains. Thinking Skills and Creativity, 6, 1-13.

Mayer, R. E. (2009). Clickers in college classrooms: Fostering learning with questioning methods in large lecture classes. Contemporary Educational Psychology, 34, 51-57

Mercier, H., \& Sperber, D. (2011). Why Do Humans Reason? Arguments for an Argumentative Theory. Behavioral and Brain Sciences , 34 (2), 57-111.

Dwyer, C. P., Hogan, M. J., \& Stewart, I. (2012). An Evaluation of Argument Mapping as A Method of Enhancing Critical Thinking Performance in E-learning Environments. Metacognitive Learning , 7, 219-244.

Jean, C. M., Carron, T., \& Pernelle, \&. P. (2012). Observe And React: Interactive Indicators for Monitoring Pedagogical Sessions. Int. J. Learning Technology , 7 (3), 277-296.

Kunsting, J., Kempf, J., \& Wirth, J. (2013). Enhancing Scientific Discovery Learning Through Metacognitive Support. Contemporary Educational Psychology , 38, 349-360.

Kwan, Y. W., \& Wong, A. F. (2015). Effects of The Constructivist Learning Environment on Students Critical Thinking Ability: Cognitive and Motivational Variables as Mediator. International Journal of Educational Research , 70, 68-79.

Pintrich, P. R. (2002). The Role of Metacognitive Knowledge in Learning, Teaching, and Assessing. College of Education, The Ohio State University , 41 (4).

Rahmawati, A. N., Widoretno, S., Suciati, Sajidan, \& Ariyanto, J. (2015). Peningkatan Kuantitas dan Kualitas Pertanyaan Peserta Didik melalui Penerapan Discovery Learning pada Pembelajaran Biologi di Kelas XI MIPA 4 SMA N 7 Surakarta.

Rodzalana, S. A., \& Saat, M. M. (2015). The Perception of Critical Thinking and Problem Solving Skill Among Malaysian Undergraduate Students. Social and Behavioral Sciences. 172, 725-732. Kuala Lumpur: Elsevier.
Rustaman, N. (2007). Ilmu dan Aplikasi Pendidikan. Bandung: PT. Imperial Bakti Utama.

Saavedra, A. R., \& Opfer, V. D. (2012). Teaching and learning 21st Century Skills : Lesson from The Learning Science. Asia Society Partnership for Global Learning: RAND Corporation.

Sarabeth, W. (2013). The Effects Of Brainscape's Confidence-Based Repition On Two. Master's Project, Fredonia, New York.

Sim, L. L. (2013). An inquiry of Teachers' Perception on The Relationship Between Higher Order Thinking Nurturing and Liberal Studies Public Assessment in Hong Kong. Hong Kong Teachers' Centre Journal , 12, 183-215.

Thomas, R., Dougherty, M. R., \& Buttaccio, D. R. (2014). Memory Constraints on Hypothesis Generation and Decision Making. Current Directions in Psychological , 23 (4), 264-270.

Veermans, K. (2002). Intelligent Support for Discovery Learning. Enschede, The Netherlands: Twente University Press.

Williams, J. J., \& Lombrozo, T. (2010). The Role of Explanation in Discovery and Generalization: Evidence From Category Learning. Cognitive Science A Multidisciplinary Journal , 34, 776-806. 